\title{
Multiple Anomalies Associated with a Small Extra Metacentric Autosome
}

\author{
A. B. MUKHERJEE ${ }^{\star}, M$. W. PARTINGTON†‡, NANCY E. SIMPSON†, \\ and KATHLEEN A. WALMSLEY
}

From the Departments of Biology and Paediatrics, Queen's University, Kingston; and the Ontario Hospital School, Smiths Falls, Canada

In man there are three well-known syndromes that are associated with an extra autosome. These are Down's syndrome (mongolism) with 21-trisomy (Lejeune, Gautier, and Turpin, 1959; Jacobs et al., 1959; Böök, Fraccaro, and Lindsten, 1959), 13-15 trisomy (Patau et al., 1960), and 17-18 trisomy (Edwards et al., 1960; Smith et al., 1960). There have been five previously reported patients with a small extra metacentric chromosome whose origin could not be identified (Frøland, Holst, and Terslev, 1963; Gustavson, Atkins, and Patricks, 1964; Taft, Dodge, and Atkins, 1965; Smith et al., 1965; Hultén et al., 1966). The chromosomes were, however, morphologically similar to the one reported here. In all five cases the patients were male and chromatin negative. The chromosomes were examined from a number of parents and sibs of the above patients: one normal mother had an extra chromosome which was identical to that in her son (Smith et al., 1965), and one sister was a 21-trisomy with typical features of Down's syndrome (Gustavson et al., 1964).

In this communication we describe a boy with multiple anomalies and an additional small metacentric autosome.

\section{Clinical and Family History}

The patient was born in December 1958 at full term after a normal pregnancy; the labour lasted 10 hours and forceps were used. The birthweight was $2721 \mathrm{~g}$. Feeding was poor, with frequent changes of formula and episodes of constipation and vomiting. The first tooth appeared at 7 months. His general development was retarded; he sat alone at the age of 13 months, has never walked unsupported, and no speech has developed.

\footnotetext{
Received November 7, 1967.

^ Present address: Division of Human Genetics, Department of Paediatrics, 86 Hodge Avenue, Buffalo, New York, U.S.A.

† Queen Elizabeth II Scientist.

$¥$ Reprint requests should be sent to $M$. W. Partington, Dept. of Paediatrics, Queen's University, Kingston, Ontario, Canada.
}

On examination at the age of 8 years he was an obviously retarded but happy child. He liked attention from other people and would squeal repeatedly if this were not provided. He liked to move around the ward in a wheelchair and observe what was going on. No speech was evident, and his play consisted of the repetitive manipulation of a small rubber toy against his mouth. He had an asymmetrical bird-like face, the right side being smaller than the left (Fig. 1). The head circumference was $48.25 \mathrm{~cm}$. There were no epicanthic folds or Brushfield spots. The ears were normally shaped but somewhat low set, with the top of the auricles on the same horizontal plane as the eyebrows. The palate was normal. His general habitus was long and

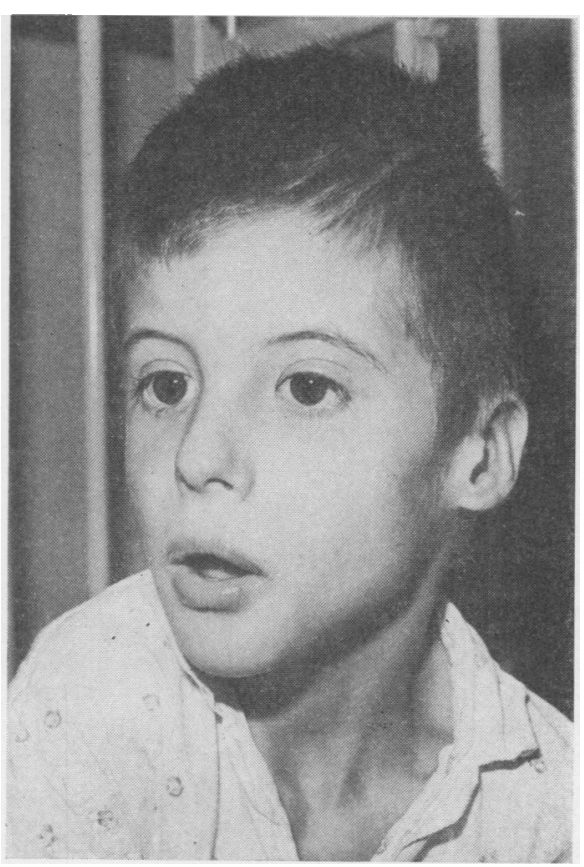

FIG. 1. A ppearance of the patient at the age of 8 years. 
TABLE I

CHROMOSOME ANALYSES OF PATIENT, HIS NORMAL SIB, AND PARENTS

\begin{tabular}{|c|c|c|c|c|c|c|c|c|}
\hline & \multicolumn{6}{|c|}{ Chromosome Counts } & \multirow{2}{*}{$\begin{array}{l}\text { Karyotype } \\
\text { Analyses }\end{array}$} & \multirow{2}{*}{ Pattern of DNA Synthesis } \\
\hline & 44 & 45 & 46 & 47 & 48 & Total & & \\
\hline $\begin{array}{l}\text { Patient } \\
\text { Mother } \\
\text { Father } \\
\text { Normal sib }\end{array}$ & $\begin{array}{l}0 \\
1 \\
0 \\
2\end{array}$ & $\begin{array}{l}2 \\
1 \\
2 \\
0\end{array}$ & $\begin{array}{r}9 \\
48 \\
45 \\
37\end{array}$ & $\begin{array}{r}41 \\
1 \\
0 \\
1\end{array}$ & $\begin{array}{l}0 \\
0 \\
1 \\
0\end{array}$ & $\begin{array}{l}52 \\
51 \\
48 \\
40\end{array}$ & $\begin{array}{l}47, X Y, ?+ \\
46, X X \\
46, X Y \\
46, X Y\end{array}$ & $\begin{array}{l}\text { Normal, extra chromosome labelled early } \\
\text { Normal, one late-labelled X chromosome } \\
\text { Normal } \\
\text { Normal }\end{array}$ \\
\hline
\end{tabular}

^ Chromosome conference: Standardization in Human Cytogenetics, 1966.

thin, with a height of approximately $117 \mathrm{~cm}$. and weight of $20 \mathrm{~kg}$. There was much soft brown hair on the arms and legs. There was a thoracolumbar scoliosis convex to the right. The heart sounds were normal with no added sounds. The arms and legs showed gross muscular wasting. The tendon jerks were brisk in the arms, but the tone was normal and he was able to move and manipulate his hands with ease. The legs showed moderate spasticity with very brisk knee jerks (clonus) and tight contracted Achilles tendons drawing his feet into equinus; there were no ankle jerks and the plantar responses were equivocal. The abdomen was moderately distended, with faeces palpable in the descending colon. The external genitalia were normal, but the bladder was palpable above the pubis.

Investigation showed a normal blood count. The electrocardiogram was suggestive of septal hypertrophy. The urine was normal, with a normal pattern of amino acids on chromatography; the ferric chloride and nitroprusside tests were negative. An intravenous pyelogram showed a double collecting system on the left, with bilateral hydronephrosis and hydroureter; there was gross reflux on the left side into the ureter draining the lower pole of the left kidney; further investigation showed no anatomical obstruction to the outflow of urine. Barium examination of his gastro-intestinal tract was negative. The electroencephalogram was normal.

The patient has a normal brother aged 4 years. A third pregnancy of the mother resulted in a macerated male foetus born at 8 months and apparently dead for two weeks before delivery; no studies were performed on the aborted foetus. The father was 25 years and the mother 24 years of age at the time of the birth of the patient, and were not consanguineous. The father has a sister who is slightly mentally retarded but able to do simple household chores. All other first-degree relatives are said to be normal.

\section{Cytological Investigations}

Sex Chromatin. No sex chromatin (Barr bodies) or any small chromatin dots which might be considered to be part of an X chromosome were found in 400 nuclei which were scored. In addition, 300 polymorphonuclear neutrophils were examined for structures that could be considered to be drumsticks or sessile female sex appendages, with negative results.

Chromosome Studies. A modification of the method described by Moorhead et al. (1960) was used for culturing leucocytes from peripheral blood, and chromosomes were labelled with ${ }^{3} \mathrm{H}$-thymidine* in order to observe the terminal pattern of replication of DNA. Autoradiographic technique similar to that of Schmid's (1963) was followed, using Kodak $\mathrm{NTB}_{3}$ nuclear track liquid emulsion.

Two cultures were grown of the patient's leucocytes taken on different days. Karyotypes were made of the first and autoradiographs of the second culture. Karyotypes and autoradiographs were also made from cultures of leucocytes grown from blood drawn from the parents and the normal sib.

Out of 52 mitotic cells from the patient, 41 had 47 chromosomes (see Table I). The extra chromosome was small, metacentric, and there were no visible satellites (Fig. 2 and 3). Cells with 47 chromosomes had a normal karyotype plus an extra metacentric autosome $(47, \mathrm{XY}, ?+)$ which was also found in cells with non 8 modal chromosome counts. Cells from the parent and the brother had normal karyotypes (see Table I) Deviations in chromosome number were within limits of those normally found using current cytological procedures.

The autoradiographs of chromosomes from the patient, parents, and the normal sib showed normal replication patterns. The extra metacentric chromosome in the patient was not late replicating in a large majority of metaphases (see Table II), nor were any chromosomes from the parents or brother other than one $\mathrm{X}$ chromosome from the mother (Table I).

\section{Dermatoglyphic Findings}

The palms and soles were printed using the Faurot method. Dermal patterns on the hands and feet are illustrated in Fig. 4.

The patient had arches on the second finger of the left hand and the first finger of the right hand, patterns that are uncommon in controls. In 500 normal male Canadian children (I. A. Uchida, H. C. Soltan, N. E. Simpson, and J.R. Miller, unpublished data), the frequency of arches is $6.0 \%$ for the left second finger and $1.4 \%$ for the right first finger. The remainder of the fingers had ulnar loops which occur commonly in the above control. The total ridge count for 10 fingers of the patient was 50 , which is low compared to that of 140 ( \pm a standard deviation of 47.5) in Canadian male children.

$\star$ Tritiated thymidine (specific activity $1.9 \mathrm{Ci} / \mathrm{mM}$ ) was obtained from Schwarz Bioresearch, Orangeburg, New York. 

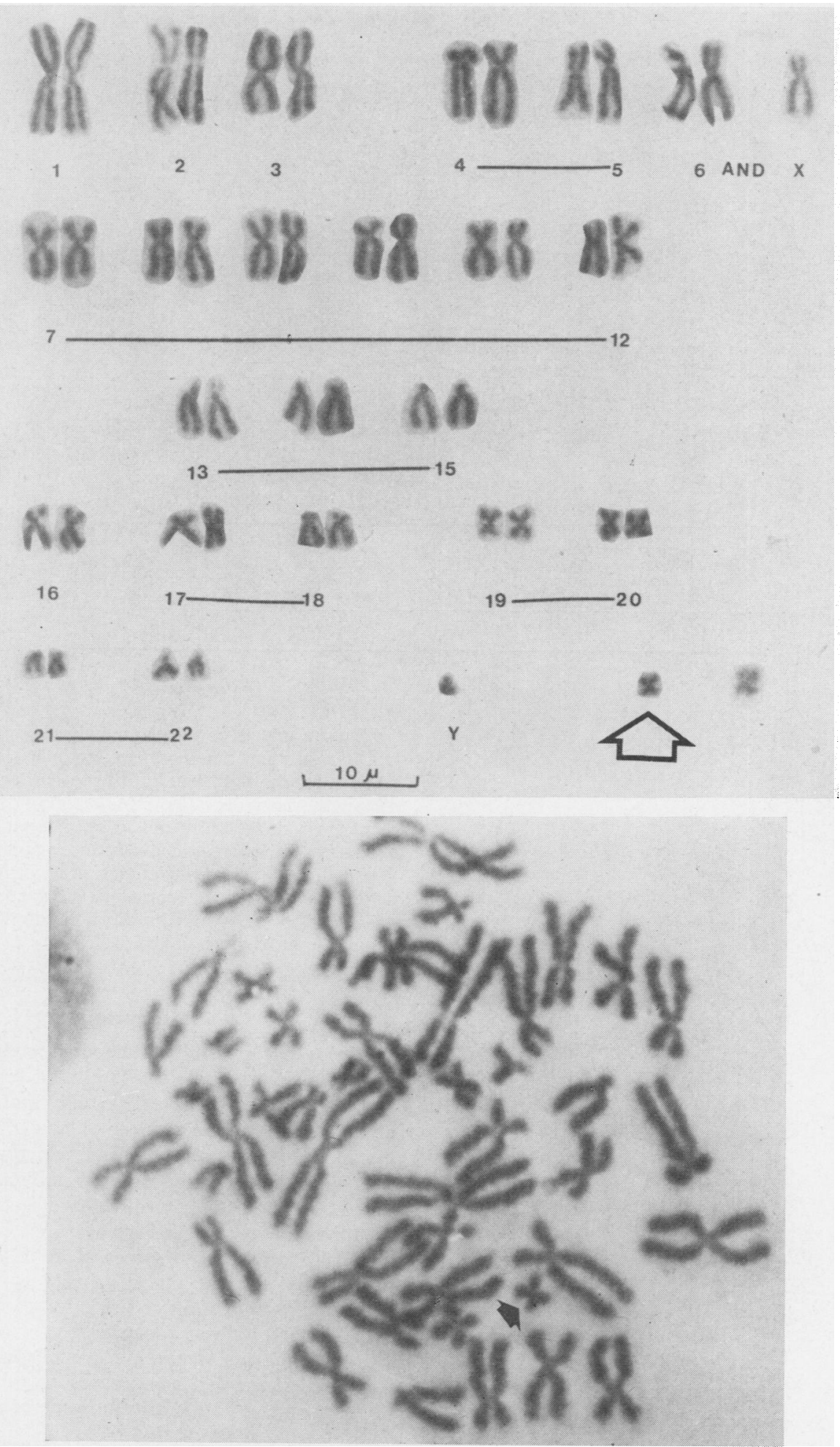

FIG. 2. Metaphase plate and karyotype shows 47 chromosomes, the additional metacentric chromosome being indicated by an arrow. In the ideogram the extra chromosome has been placed after Y, followed by a greater enlargement of it. Peripheral blood culture. (Acetoorcein stain.) 


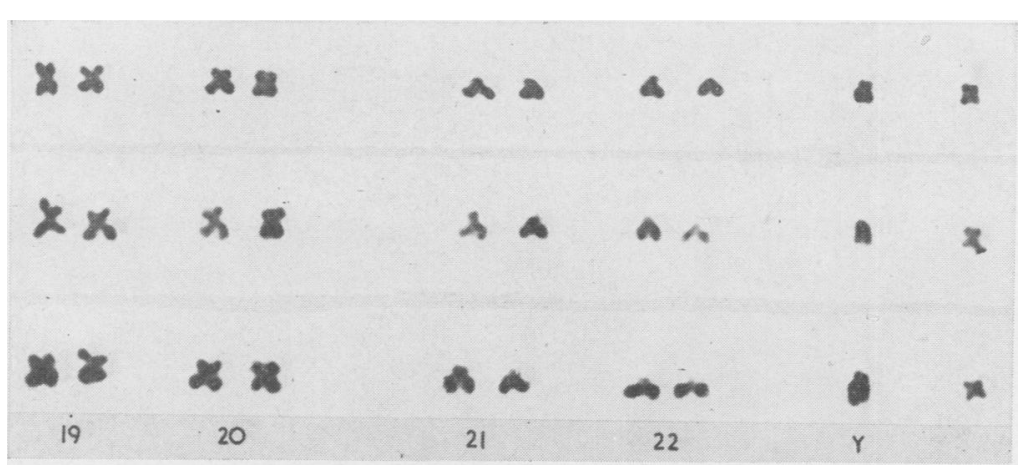

Fig. 3. Chromosomes from four cells other than in Fig. 2; only Nos. 19-20, 21-22, Y, and the additional chromosome have been arranged. Peripheral blood culture. (Aceto-orcein stain.)

TABLE II

GRAIN COUNTS ON CHROMOSOMES OF PATIENT (AFTER 4 HOURS IN CONTACT WITH 3H-THYMIDINE)

\begin{tabular}{c|c|c|c}
\hline $\begin{array}{c}\text { No. of Labelled Cells Where } \\
\text { Extra Chromosome had } \\
\begin{array}{c}\text { Grains (1-2) (other chromo- } \\
\text { somes free of grain) }\end{array}\end{array}$ & $\begin{array}{c}\text { Total No. } \\
\text { of Cells } \\
\text { Counted }\end{array}$ & $\begin{array}{c}\text { No. of Labelled Cells Where } \\
\text { Extra Chromosome was } \\
\text { Free of Grains (when other } \\
\text { chromosomes are labelled) }\end{array}$ & $\begin{array}{c}\text { Total No. } \\
\text { of Cells } \\
\text { Counted }\end{array}$ \\
\hline 5 & 45 & 3 & 39 \\
\hline
\end{tabular}
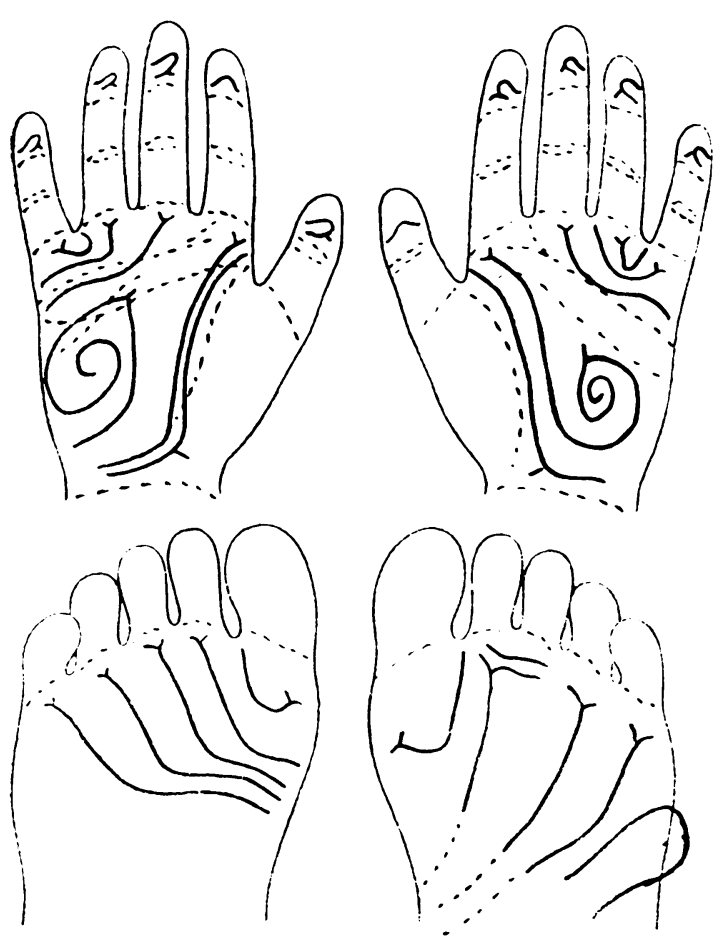

FIG. 4. Main lines and patterns of dermal ridges on palms and soles.
The atd angles of the palms were large: $83^{\circ}$ for the left hand of the patient compared with $46^{\circ}$ in the controD, and $69^{\circ}$ for the right hand of the patient compared with $45^{\circ}$ in the control. The whorls found in the hypothenar regions on both hands of the patient occur on $2 \%$ of left and $5 \%$ of right hands in Canadian male children.

The distal loops in the hallucal areas of the feet of the patient have low ridge counts : 14 for the left and 17 for the right foot, compared to mean counts 32 and 30 for left and right feet in controls.

\section{Discussion}

It was not possible to determine the origin of the extra chromosome in the patient from the cytological studies. Lack of sex chromatin in interphase nuclei and the absence of late-labelling of the metacentric chromosome in our patient suggest that the origin of this chromosome is unlikely to be from the $\mathrm{X}$ chromosome. Since the supernumerary chromosome of the patient was not late-labelling nor were any chromosomes from his parents or brother (except the one $\mathrm{X}$ chromosome from his mother), identification of the extra chromosome by autoradiography was unsuccessful.

Because of its size the extra chromosome may have originated by isochromosome formation of the short arm of an $\mathrm{E}$ chromosome or a pericentric 
TABLE III

CLINICAL FEATURES OF PATIENTS WITH SMALL EXTRA METACENTRIC CHROMOSOME

\begin{tabular}{|c|c|c|c|c|c|c|c|}
\hline \multirow[t]{2}{*}{ Clinical Feature } & \multirow[t]{2}{*}{$\begin{array}{c}\text { Frøland et al. } \\
(1963)\end{array}$} & \multirow[t]{2}{*}{$\underset{(1964)}{\text { Gustavson } e t \text { al. }}$} & \multirow[t]{2}{*}{$\begin{array}{c}\text { Taft et al. } \\
\quad(1965)\end{array}$} & \multicolumn{2}{|c|}{$\underset{(1965)}{\text { Smith et }}$ al. } & \multirow[t]{2}{*}{ 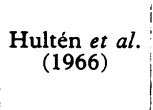 } & \multirow[t]{2}{*}{ Present Case } \\
\hline & & & & Son & Mother & & \\
\hline $\begin{array}{l}\text { Sex } \\
\text { Age (yr.) } \\
\text { IQ or DQ } \\
\text { Head: } \\
\text { Microcrania } \\
\text { Shape } \\
\text { Facies } \\
\text { Eyes: } \\
\text { Coloboma } \\
\text { Epicanthus } \\
\text { Low-set ears } \\
\text { Loose neck skin } \\
\text { High palate } \\
\text { Retarded dentition } \\
\text { Extremities: } \\
\text { Spasticity } \\
\text { Slender arms and fingers } \\
\text { Syndactyly } \\
\text { Ulnar deviation of hands } \\
\text { Talipes } \\
\text { Single palmar crease one hand } \\
\text { Gynaecomastia } \\
\text { Renal system } \\
\text { Oligospermia }\end{array}$ & $\begin{array}{c}\mathrm{M} \\
2 \\
65 \\
+ \\
\mathrm{N} \\
\text { Small mouth } \\
\text { and jaw } \\
\mathrm{O} \\
\mathrm{O} \\
+ \\
+ \\
+ \\
+ \\
+ \\
+ \\
+ \\
+ \\
\text { Calcaneovalgus }\end{array}$ & $\begin{array}{c}\text { M } \\
16 \\
22 \\
\stackrel{+}{\mathbf{N}} \\
\text { Small mouth } \\
\text { O } \\
\text { O } \\
+\end{array}$ & $\begin{array}{l}+ \\
+ \\
+ \\
\mathbf{O} \\
\mathbf{O} \\
+ \\
+ \\
+ \\
\mathbf{N} \\
\mathbf{O} \\
\mathbf{O} \\
\mathbf{O}\end{array}$ & $\begin{array}{l}\mathbf{M} \\
30 \\
\mathbf{N} \\
\mathrm{O} \\
\mathbf{N}\end{array}$ & $\begin{array}{l}\mathbf{F} \\
\mathbf{N}\end{array}$ & $\begin{array}{c}\text { One side } \\
\text { 'Aplasia' } \\
\text { O }\end{array}$ & \begin{tabular}{|c|c|c|} 
& \\
28 \\
+ \\
Asymmetrical \\
Bird-like \\
\\
O \\
O \\
+ \\
O \\
O \\
O \\
+ \\
+ \\
O \\
O \\
Equinus \\
O \\
O \\
Double ureter on \\
left with hydro- \\
nephrosis
\end{tabular} \\
\hline
\end{tabular}

$\mathrm{N}=$ normal $;+=$ present $; \mathrm{O}=$ absent $; \mathrm{I}=$ intelligence quotient $; \mathrm{DQ}=$ developmental quotient.

inversion resulting from breakage in a $G$ chromosome. The latter is unlikely since there are no visible satellites on the chromosome found in the patient. It could, however, result from a translocation or deletion of some other non-satellited autosome.

The clinical features reported for patients with similar looking small extra metacentric chromosomes are too heterogeneous (see Table III) to suggest a distinct syndrome, as has been done for the wellknown syndromes associated with other autosomal trisomies of the D, E, and G groups. Though the small metacentric chromosomes look alike, none have been identified; there is no evidence that they have the same origin, and the variation in phenotypes, including an apparently normal mother (Smith et al., 1965), suggests a variable origin of the chromosome in patients who have been reported, or no relation between phenotype and chromosome at all.

The patient had remarkable dermatoglyphs. Unusual dermal patterns associated with aneuploidy and congenital abnormalities with no visible chromosomal defects are reviewed by Alter (1966). Some patterns are distinctive in their association more commonly with a single chromosome than in normal controls; for example, the arch fibular or arch fibular-S pattern on the hallucal area of the foot associated with $\mathrm{D}_{1}$ trisomy (Uchida, Patau, and
Smith, 1962) and the arch tibial associated with Gtrisomy (Cummins, 1939; Walker, 1958). For the most part, however, an increase of some pattern frequencies is more commonly associated with more than a single chromosome and has been observed in apparently euploid but clinically abnormal conditions such as the Rubinstein-Taybi syndrome (Giroux and Miller, 1967; Padfield, Partington, and Simpson, 1968). A large atd angle is most often found in aneuploid conditions involving the 17-18 or 21-22 chromosomes, in XO individuals, and in persons with a deleted 4-5 chromosome (cri-du-chat syndrome) (Alter, 1966). Low ridge counts are associated with a number of aneuploid conditions and in the Rubinstein-Taybi syndrome (see Alter, 1966).

It is clear that an extra chromosome cannot be identified by dermatoglyphs, but groupings of patients with similar clinical features and the same chromosomal changes have characteristic dermal pattern frequencies different from controls. It therefore seems important to describe the dermatoglyphs along with clinical features and cytological findings when reporting aneuploidy in which the chromosomal change cannot be identified.

Apart from the well-established trisomies there appear to be a number of patients with small extra metacentric autosomes and variable clinical features. Each condition is presumably rare, and continued 
reporting of these may make it possible eventually to classify these patients into homogeneous groups.

\section{Summary}

An 8-year-old boy with several congenital anomalies, including severe mental retardation, has been described. Chromosomal analysis showed a modal number of 47 , the extra chromosome being small and metacentric with no visible satellites. Lack of a late-labelled chromosome and absence of sex chromatin suggest that the origin of the extra chromosome is not from an $\mathrm{X}$ chromosome.

Karyotypes and autoradiographs of parents and a brother were normal.

Unusual dermatoglyphic patterns were noted.

We would like to thank Dr. H. E. F. Frank of the Ontario Hospital School, Smiths Falls, for his co-operation in this study. Support from N.R.C. Grant A3749 and M. R. C. Grant 1876 is gratefully acknowledged.

\section{REFERENCES}

Alter, M. (1966). Dermatoglyphic analysis as a diagnostic tool. Medicine (Baltimore), 46, 35.

Böök, J. A., Fraccaro, M., and Lindsten, J. (1959). Cytogenetical observation in mongolism. Acta paediat. (Uppsala), 48, 453.

Chicago conference (1966). Standardization in human cytogenetics. Ed. by D. Bergsma, J. L. Hamerton, and H. P. Klinger. Birth Defects; Original articles series, $2,1$.

Cummins, H. (1939). Dermatoglyphic stigmata in mongoloid imbeciles. Anat. Rec., 73, 407.
Edwards, J. H., Harnden, D. G., Cameron, A. H., Crosse, V. M., and Wolf, O. H. (1960). A new trisomic syndrome. Lancet, 1, 787.

Frøland, A., Holst, G., and Terslev, E. (1963). Multiple anomalies associated with an extra small autosome. Cytogenetics, 2, 99.

Giroux, J., and Miller, J. R. (1967). Dermatoglyphics of the broad thumb and great toe syndrome. Amer. F. Dis. Child., 113, 207.

Gustavson, K. H., Atkins, L., and Patricks, I. (1964). Diverse chromosomal anomalies in two siblings. Acta paediat. (Uppsala), 53, 371 .

Hultén, M., Lindsten, J., Fraccaro, M., Mannini, A., and Tiepolo, L. (1966). Extra minute chromosome in somatic and germ-line cells of the same person. Lancet, 2, 22.

Jacobs, P. A., Baikie, A. G., Court Brown, w. M., and Strong, J. A. (1959). The somatic chromosomes in mongolism. ibid., 1, 710.

Lejeune, J., Gautier, M., and Turpin, R. (1959). Les chromosomes humains en culture de tissus. C. R. Acad. Sci. (Paris), 248, 602.

Moorhead, P. S., Nowell, P. C., Mellman, W. J., Battips, D. M., and Hungerford, D. A. (1960). Chromosome preparations of leukocytes cultured from human peripheral blood. Exp. Cell Res., 20, 613.

Padfield, C. J., Partington, M. W., and Simpson, N. E. (1968). The Rubinstein-Taybi syndrome. Arch. Dis. Childh., 43, 94.

Patau, K., Smith, D. W., Therman, E., Inhorn, S. L., and Wagner, H. P. (1960). Multiple congenital anomaly caused by an extra autosome. Lancet, 1, 790.

Schmid, W. (1963). DNA replication patterns of human chromosomes. Cytogenetics, 2, 175.

Smith, D. W., Patau, K., Therman, E., and Inhorn, S. L. (1960). A new autosomal trisomy syndrome: Multiple congenital anomalies caused by an extra chromosome. 7 . Pediat., 57, 338 .

Smith, K. D., Steinberger, E., Steinberger, A., and Perloff, W. H. (1965). A familial centric chromosome fragment. Cytogenetics, 4, 219.

Taft, P. D., Dodge, P. R., and Atkins, L. (1965). Mental retardation and multiple congenital anomalies. Amer. F. Dis. Child., $109,554$.

Uchida, I. A., Patau, K., and Smith, D. W. (1962). Dermal patterns of 18 and $\mathrm{D}_{1}$ trisomics. Amer. F. hum. Genet., 14, 345.

Walker, N. F. (1958). The use of dermal configurations in th diagnosis of mongolism. Pediat. Clin. N. Amer., 5, 531 . 